\title{
ASSESSING YOUTH ENGAGEMENT IN THE PRESERVATION AND PROMOTION OF CULTURE HERITAGE: A CASE STUDY IN KORÇA CITY, ALBANIA
}

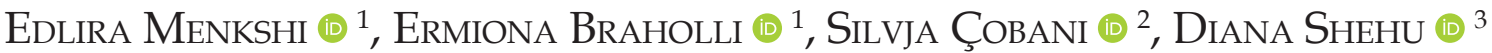 \\ ${ }^{1}$ Department of History and Geography, University Fan S.Noli, Korçë, Albania \\ ${ }^{2}$ Department of Maths and Physics, University Fan S.Noli, Korçë, Albania \\ ${ }^{3}$ Department of Rural Tourism Management, Agricultural University of Tirana, Albania
}

Manuscript received: February 4, 2021

Revised version: March 13, 2021

\begin{abstract}
Menkshi E., Braholli E., Çobani S., Shehu D., 2021. Assessing Youth engagement in the preservation and promotion of culture heritage: A case study in Korça City, Albania. Quaestiones Geographicae 40(1), Bogucki Wydawnictwo Naukowe, Poznań, pp. 109-125. 9 figs, 5 tables.

ABSTRACT: The engagement of young people is already considered essential for preservation and promotion of culture heritage. United Nations Educational, Scientific and Cultural Organisation (UNESCO), the European Commission, national governments and numerous organisations have undertaken a series of initiatives and projects that are aimed at engaging young people in the preservation and promotion of cultural values from the international level to the local ones. The aim of this study is to identify and analyse the role of youth in cultural heritage preservation and promotion in a local area, after considering the importance of their engagement. The research has been conducted on the basis of quantitative and qualitative data, which has been collected from primary and secondary sources. A survey is conducted in a local urban area (the city of Korça) that is rich in cultural heritage. This city is located in the south-eastern part of Albania. The data gathered through the questionnaire was later coded and analysed using SPSS v. 20 software. Based on the results of the research, the engagement of youth, especially students, in maintenance of archaeological sites, museums and libraries, training culture programs, guide walk tourist itineraries and participation in local heritage projects, enhance not only their awareness concerning heritage values, but also contributes towards their preservation and promotion. It is observed from the survey that the level of awareness of young people interviewed is higher among those who have been engaged in projects and cultural activities for preservation and promotion of heritage values. In terms of willingness expressed by young people, it is important to emphasise the role that education system, youth and heritage organisations and national and local government ought to play in encouraging the initiatives that involve more young people in heritage activities and projects.
\end{abstract}

KEY wORDS: Korça - Albania, youth, cultural heritage, engagement, preservation, promotion

Corresponding Author: Edlira Menkshi,eda_ndreko@yahoo.com

\section{Introduction}

In simple terms, heritage can be considered everything that has been inherited from the past to the present and that has values for a community, nation or for the entire human society.
Regarding Yahaya, the scope and definition of heritage has broadened from tangible to intangible and is internationally agreed to include tangible heritage (UNESCO 1972) - such as monuments and groups of buildings and sites - as well as intangible heritage (UNESCO 2003) - such as 
practices, representations, expressions, knowledge, skills, the instruments, objects, artefacts and cultural spaces associated with their environments and communities (Yahaya 2006). In a broader meaning, the Convention on the Value of Cultural Heritage for Society (Article 2) defines that cultural heritage is a group of resources inherited from the past which people identify, independently of ownership, as a reflection and expression of their constantly evolving values, beliefs, knowledge and tradition. It includes all aspects of environment resulting from the interaction between people and places through time (CE 2005). According to the Convention, the preservation and transmission of these heritage values to the future generations is actually the responsibility of our society. Furthermore, everyone is encouraged to participate in the process of identification, study, interpretation, protection, conservation and preservation of cultural heritage (Art. 12). Considering the importance of preservation and promotion of cultural heritage values for countries and human society, United Nations Educational, Scientific and Cultural Organisation (UNESCO), International Council on Monuments and Sites (ICOMOS), the International Council on Museums (ICOM), the International Centre for the Study of the Preservation and Restoration of Cultural Heritage (ICCROM), the European Commission, Council of Europe and European Union institutions, national governments and numerous civil society organisations have undertaken a series of initiatives and policies from the international level to the local one (Chapuis et al. 2009). In many countries several programs have been developed in collaboration with UNESCO (World Heritage Education Programme, World Heritage Volunteers Initiative, European Heritage Volunteers and World and Sustainable Tourism Programme) and projects for the protection and promotion of the cultural heritage diversity, especially those activities that aim to increase young people's awareness and their engagement. Recently, through heritage projects, young people around the world are (UNESCO 2014) increasingly getting involved in the preservation and promotion of heritage values, recognizing that heritage does not belong to the past, but is also part of their current identity (United Nations). One of the components of European Cultural Heritage Strategy for the 21st Century critically focuses on the relationship between heritage and shared knowledge, supporting the increasing of the training and the involvement of young people in cultural heritage activities (CE 2018). Preserving cultural heritage as a part of the identity, European Culture Forum (Milano, December 2017) defined the engagement of young people in conservation, enhancement and transmission of cultural heritage as one of the Forum's initiatives (EC 2018). What was strongly emphasised by the authorities at the Forum was to bring youth close to cultural heritage. Young people have a lot of ideas, so local initiatives need to bring them together, because behind the ideas there are the projects. The Forum launched the 2018 European Year of Culture Heritage, which aimed to encourage young people to appreciate cultural heritage and to participate in activities for preserving and promoting their values (as ascertained by the author's participation in the Forum). To fulfil this initiative, the UNESCO and EU undertook a series of awareness activities and projects to strengthen the connections between cultural heritage, youth and education, such as the European Young Heritage Professionals Forum in Zadar Croatia, May, 2019 (UNESCO/EU 2019). Similar to these initiatives and projects, each country should encourage the participation of young people in voluntary activities on awareness and protection of the cultural wealth of their country as well as others.

Cultural heritage values such as archaeological objects, historical monuments, knowledge, traditions, works, beliefs and experiences transmitted from the past to the present are essentially important, because communities identify themselves through them and what they associate with provides them with a sense of belonging (Karadeniz 2020). To insure their continuity for future generations, these values should be used when considering their preservation and conservation. The cultural heritage preservation involves the preservation of physical heritage from being damaged, destroyed or transformed; further, it also encompasses the transmission of intangible values by a community to reveal their existence (Hani et al. 2012). In this context, according to researchers, education would be the best approach to execute the process of the preservation of cultural heritage values. Education plays an important role in raising the awareness levels of young people about the protection and transmission 
of cultural heritage (UNESCO, World Heritage Education Programme). Furthermore, education on culture heritage enhances people's capability to become not only citizens able to live in society with a greater sense of fulfilment but also responsible citizens in relation to the perceived moral obligation towards the protection of cultural heritage (Gesche-Koning 2018). According to the glossary given to the Faro Convention Action Plan Handbook 2018-2019, cultural heritage education refers to the development and implementation of diverse and creative formal and non-formal education activities, curricula, and games for children under 18 years old, in line with the principles of the Faro Convention (FCAPT 2018). According to Jagielska-Burduk and Stec (2019), the legal framework of European policy initiatives is aimed at giving heritage education a practical dimension, through enthusiastic adoption of those outreach activities which endeavour to establish a cultural mechanism for the perennial sharing and promotion of heritage knowledge. (Jagielska-Burduk, Stec 2019). The education policies in many European countries have encouraged the integration of cultural heritage in school through the educational programmes and numerous other activities in heritage centres, museums and heritage sites (Gesche-Koning 2018).

\section{Heritage and youth engagement in Albania}

In terms of cultural heritage, Albania has acceded and ratified various international conventions and European conventions for the protection and preservation of tangible and intangible cultural heritage. These include the Convention Concerning the Protection of the World Cultural and Natural Heritage (1989), the Convention on the Means of Prohibiting and Preventing the Illicit Import, Export and Transfer of Ownership of Cultural Property (2002), the Convention for Safeguarding of the Intangible Cultural Heritage (2006), the Convention on the Protection and Promotion of the Diversity of Cultural Expressions (2006) and the European Convention for the Protection of Archaeological Heritage (2007). The country is very rich with cultural and natural heritage properties. Four of these properties are registered in World
Heritage List, such as the cultural properties of the Archaeological Site of Butrint (1992) and the Historic Centres of Gjirokastra and Berat (2005, 2008). Albania is also part of the natural property of the Ancient and Primeval Beech Forest of the Carpathians and Other Regions of Europe (2007) and lake Ohrid (Albanian part) as part of Natural and Cultural Heritage of the Ohrid Region in 2019 (UNESCO 2020a). Regarding the intangible heritage, the Albanian Folk Iso-Polyphony is registered in the World Intangible Cultural Heritage List in 2005 (UNESCO 2020b). The preservation, protection, evaluation and administration of cultural heritage in Albania function based on the Law On Cultural Heritage and Museums and other legal and sub-legal provisions. The Ministry of Culture and several specialised institutions are engaged in the management of and utilising of cultural heritage sites for tourism development (KM 2018). However, the preservation and conservation of cultural heritage in the country encounters a number of problems related to management practices and lack of government financing investment. Although the law and institutions consider the preservation and conservation of cultural heritage as very important, the level of awareness, participation and involvement of community and especially youth in the related processes is low.

United Nations for statistical purposes defines youth as those persons between the ages of 15 and 24 years, but there is no universally agreed international definition (United Nations n.d.). Based on many standards and documents of European Union and European Council, the Institute of Statistics in Albania (INSTAT) defines young people or youth as those persons whose age ranges between 15 and 29 years (CRCA, 2018). Referring to statistical data, with a number of 596,624 pupils and students enrolled in the primary, secondary and higher levels of education (Peci, Nikolli 2017), Albania continues to be a relatively young country, where $23.2 \%$ of the population is aged 15-29 years (CRCA/ ECPAT 2020). In the National Strategy for Youth (2007-2013), encouraging and promoting youth volunteerism was mentioned to ensure that it can have an important role in the development of the country and the youth. In consonance with this policy, youth volunteering has aimed at raising the awareness of young people, by increasing 
the level of encouragement offered for visits to cultural monuments and their commitment to facilitating guides (MTKR 2006). Furthermore, the organisation of youth activities in tourist areas is aimed at their promotion and protection by young people (MMSR 2015). The Albanian National Youth Network, which was created in 2015 , is a youth network composed of political forums and youth civil society groups at local and national level, and it promotes programs to support young people and their participation in decision-making at both local and central level. Apart from their engagements in the political, economic and social sphere, the participation of young people in projects and/or activities that aim to protect the cultural heritage is scarcely mentioned and remains on a low level.

Actually, youth policies are formulated by and the responsibility of the Ministry of Education, Sport and Youth, which has not created a National Youth Strategy. The project called Smile Albania aims to engage young people throughout the tourist season in all the border crossing and tourist zones, to turn Albania to a European tourist destination. This project focuses on raising the youth's awareness and their commitment to promote the beautiful nature, the cultural heritage sites and Albanian hospitality to foreign tourists, whose number in Albania has been increasing in recent years. Through the trainings conducted by the project, it is intended to promote volunteerism and employment of students during the tourist season. In support of young people's social life, in some Albanian cities there are Youth Centres, which aim to engage young people in political, social, environmental and cultural activities.

Despite the inadequacies largely characterising the initiatives of institutions and the national and local governments for the preservation and promotion of culture heritage, efforts are not underway to ensure that they are accompanied by scientific researches in terms of the role that youth can play. Based on this, the aim of this study is to identify and analyse the role of youth in cultural heritage preservation and promotion in a local area, considering the importance of their engagement. The study was initiated voluntarily by the authors, as a result of working with university students and the students' desire to engage in voluntary activities and projects aiming to promote and protect local heritage. The paper aims to analyse and survey the situation of young people in relation to their cultural awareness and their level of commitment and willingness to engage in the promotion and preservation of cultural heritage. The survey was conducted in one of the main cities, Korça city, located in the southeast of the country, rich in cultural heritage and frequented by local visitors and foreign tourists. Considering the fact that this place is already a developing tourist destination, this study can serve as a means for local policymakers to initiate education and awareness programs, as well as to actually promote the engagement of young people in the preservation of cultural heritage and the promotion of its values for the development of tourism.

\section{Culture heritage education in curricula}

In the National Strategy for Culture 2019-2025, in addition to the preservation and protection of heritage and its promotion, one of the cultural policies predicted the goals that the Ministry of Culture of Albania would pursue is the design and implementation of an educational platform through art and cultural heritage institutions and the pre-university system, with the specific objective being the Education Program Though Culture (MK 2019) The program consists of several activities undertaken by cultural heritage institutions such as the Little Archaeologist, of The Monument's Friend, My Museum etc. which aim to increase children's interest in cultural heritage values and strengthen the cooperation between the schools and the museums. In the Albanian education system, cultural heritage knowledge has been taught in all levels of education. Inheritance education begins with the integration of heritage knowledge into the school curricula. In primary education (5 years), culture, traditions and customs' knowledge is integrated in the course Education for Society. The education and awareness of cultural heritage is strengthened from the subject 'History', by acquiring knowledge about the heritage of ancient civilisations. In addition to formal education, 'History' is also learned through informal education by participation in extracurricular projects and visiting museums and cultural heritage sites.

In secondary education, pupils develop their heritage knowledge in the subjects of History and Geography. In 9th grade Geography, students 
analyse the interaction between the physicalgeographical, social and economic systems of Albania and the area surrounding Albanian. One of the main issues dealt with is the Natural and Cultural Heritage of Albania and the development of tourism. Regarding cultural heritage, students learn to assess and describe the following, namely: the general features of cultural heritage, its categories and the utilities associated with each of these features from the point-of-view of tourists (Ministry of Education, Sport and Youth 2019). Schools also organise activities that are related to local cultural heritage and conduct art competitions, which promote students' creative abilities in presenting cultural values.

In high school curriculum, cultural heritage is better covered in Geography. By dealing with the regional geography of Albania and other Albanian territories, the Geography of the XI grade provides students with knowledge on cultural and natural heritage, their values and their categories. In XII grade Geography (this is an optional subject), it is intended that students understand and appreciate the cultures, lifestyles and development of the world by regional over-viewing of the population, cultures and economic developments (Ministry of Education, Sport and Youth 2017). However, the knowledge that students acquire up to this level of education is considered insufficient to raise the awareness of these young age groups in the context of cultural heritage and its protection.

The study programs at Fan S. Noli University of Korça (UNIKO), have integrated the available knowledge on education for cultural heritage, but only a little and only through a meagre number of study programs. The History-Geography study program plays a major role in providing knowledge on cultural heritage, but there are also some programs - such as Master in Tourism or Tourist Guide - which provide knowledge on cultural heritage and cultural tourism. The Curriculum of the History-Geography study program offers education on heritage through the following subjects, namely: Archaeology, Ancient History, Natural and Cultural Heritage and Tourism Geography. Education and knowledge about cultural heritage are provided together with geographical analysis. Students are introduced to the definitions of heritage, world cultural heritage and European and international organisations for the preservation and protection of heritage in general (UNESCO, ICCROM) and also of the elements of cultural heritage of Albania, its categories and its protection and management. In addition, the curriculum of the master professional degree also provides knowledge on the Application of GIS Technology in Natural and Cultural Landscapes (Department of History and Geography 2020).

The teaching practices that take place in the region and in the entire country also play an important role in educating and raising awareness of students on cultural heritage and the protection of its values. Occasional visits to museums and cultural heritage sites, as part of the informal education, are as well applied to students. In addition, an important role in heritage education is played by the involvement of students of the HistoryGeography study program in internships, voluntary internships during the tourist season in the city's museums and in other activities for the promotion and protection of heritage values. These students, on the basis of their experience, attain better learning outcomes that are related to knowledge, behaviour, inspiration, critical thinking, attitude and transmission of experience to others. In determining how useful the learning outcomes of students are in encouraging them to take up the cause of cultural preservation and transmission and propagate it among their peers, an important role is played by the academic staff that is expected to play a nurturing role in encouraging and promoting students' engagement in collaborations with local institutions in the fields of heritage, tourism and environmental preservation. It is also worth mentioning the involvement of several students of the History-Geography study program in the Erasmus Mundus Program (exchange students) with the University of Porto, Portugal as a host institution, which has helped students gain knowledge and experience about cultural heritage in and out of Albania. Moreover, History and Geography students who complete their higher education are employed, and offer their services, not only as teachers in secondary and higher education, but also as specialists in cultural institutions such as museums, libraries etc. In addition to the universities, regional cultural heritage institutions (Regional Directory of Cultural Heritage, National Museum of Medieval Art, Archives) and the local government have 
initiated actions for cultural awareness of students and youth through visits to cultural heritage sites in the region. Institutions and local and regional authorities can play a significant role through funded programmes, with the objective of enhancing the interest of young people to participate in protection and promotion of heritage values (UE 2011).

Actually, the Ministry of Culture has implemented UNESCO's project (2020-2022): Community based inventory of ICH in Albania with a view to safeguarding and transmitting to future generations (UNESCO 2019). The objectives of the project are the involvement of communities in the safeguarding process through a limited national inventory in three selected districts of Albania (Korça is one of three pilot cities) as well as strengthening the transmission of living heritage-related knowledge and skills in the three regions. Some students from Fan S. Noli University are also included in the project to facilitate their contribution to the inventory elements of local intangible heritage.

\section{Culture heritage}

Korça is one of the main cities in Albania. It is located in the south-eastern part of the country; this location falls in the cross-border area with Greece and North Macedonia. The city has its historic centre with a number of heritage buildings with regional and national values. Archaeological findings identify the existence of a settlement that has been inhabited since ancient times, while written sources date the city to the first half on the 15th century (Selenica 1982). The city began to develop rapidly in the mid-nineteenth century as an important centre of the region, traditionally

Table. 1. Elements of the cultural heritage in Korça city and the surrounding area (Menkshi 2014).

\begin{tabular}{|l|l|}
\hline $\begin{array}{c}\text { Culture } \\
\text { heritage }\end{array}$ & \multicolumn{1}{|c|}{ Types of cultural heritage } \\
\hline Tangible & $\begin{array}{l}\text { Museums } \\
\text { Tradicional buildings (houses, old bazzar) } \\
\text { Religious object (churches, mosque) } \\
\text { Archaeological site }\end{array}$ \\
\hline Intangible & $\begin{array}{l}\text { Music } \\
\text { Traditions } \\
\text { Traditional food } \\
\text { Festivals (BeerFestival, religious festivals.) } \\
\text { Crafts } \\
\text { Hospitality }\end{array}$ \\
\hline
\end{tabular}

known for its important role in economic, social, educational and cultural development. Evidence of this continuous development is offered by the existence of many old buildings and other cultural heritage objects in the city and its surrounding area, protected by the national status of Cultural Monument. In addition the city and its surroundings are mentioned for their rich spiritual traditions and elements (Table 1).

Among them, museums are distinguished by the diversity of heritage objects that they collect. National Museum of Medieval Art (1980) is an important part of the historical, cultural and artistic heritage, mainly related to the Byzantine and post-Byzantine Christian heritage, and it consists of a collection of icons by 150 Albanian and foreign authors as well as artefacts made of stone, wood, metal, fabric etc. Particularly, the iconographic collection that this museum possesses is one of the largest in number (about 6500) and just as beautiful and comparable to all other Byzantine and post-Byzantine art created in neighbouring territories that are part of the former Byzantine Empire. Besides the National Museum of Medieval Art, the Museum of Education is the symbol of one of the most important historical and cultural events of all the Albanian territories, since this is the place where the opening of the first school in Albanian language on March 7, 1887 took place (MTM 2018). Well known are also Archaeological Museum, Oriental Museum Bratko, Gjon Mili Photography Museum and others with regional and local values (Fig. 1). Apart from their functions such as institution of collection, preservation and promotion of historical and cultural values, they are also considered to be an educational institution for young generation. While heritage education in classrooms contributes to the development of skills and competences that encourage students to participate in the creation of critical citizenship, informal education through cultural and heritage activities in museums develop the memory, generates emotions, identity and sense of belonging in children of the school-going age (Escribano-Miralles et al. 2020).

The architecture developed in 19th and 20th century is represented by the existence of old buildings with two to three floors, of the type of villas with aesthetic values and special architectural styles. Old bazaar is the main architecture object inherited in its current condition from the 


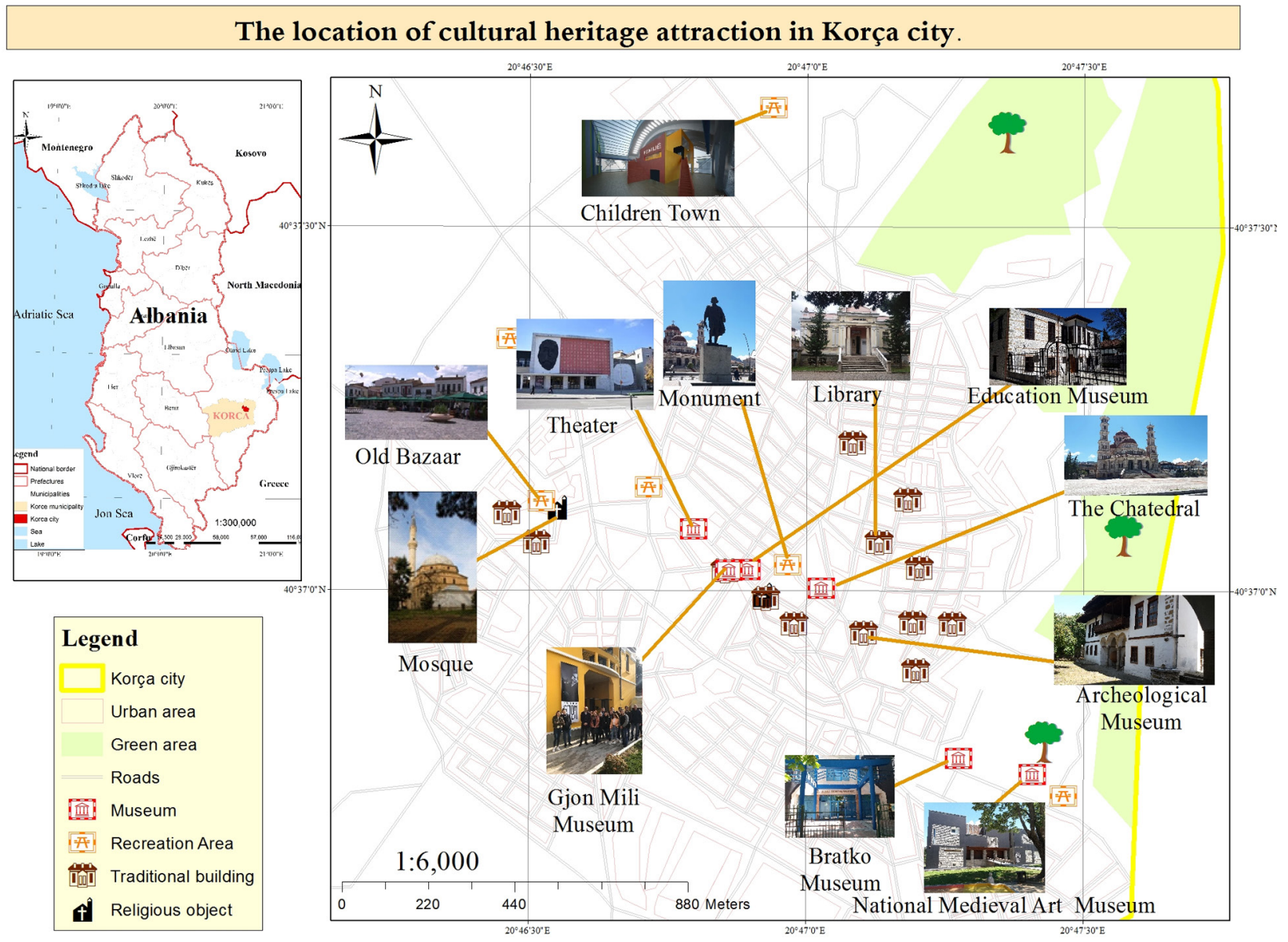

Fig. 1. The location of cultural heritage attractions in Korça city.

second half of the 19th century, and it contains many old buildings, especially shops with decorative elements. The cathedral in the centre of the city, although build in 1995, is one of the most attractive buildings with architectural and artistic values (Fig. 2).

In addition to its tangible heritage, the city is widely known for the traditions, culinary skills, celebrations and festivals and organisations such as Carnivals, the Eastern Celebration, and Beer Festivals (Menkshi, 2014). Because of traditional architecture, museums, old buildings carved or constructed out of stone, events and celebrations, the city is being visited by numerous domestic and foreign visitors recent times, which have made many of the objects of cultural heritage to be deployed towards its development. New usages of old buildings are related to their restoration and adaptation towards activities such as hotel restaurants but also commercial businesses such as souvenir shops or business centres. In addition to being adapted with new functions, the old buildings have been reconstructed (or rehabilitated), to preserve the original and authentic elements in both parts of the buildings, namely their exterior facades and interior parts (Fig. 3).

However, there are also some new buildings which have not preserved the architectural elements in the external facade (decorative elements, painting colour), disrupting the harmony of constructions, especially in the historic centre of the city. At the same time, some of old heritage buildings suffer lack of investment and are in danger of losing their values due to destruction. In general, the development of the city as a tourist destination, through the restoration, rehabilitation and reuse of heritage buildings, is aimed at preserving their historic values.

In addition, cultural heritage can also be preserved through the development of creative and cultural industries (Spiridon et al. 2014). In this context, the development of some small and medium enterprises in the city - which can be 
classified under the creative and cultural sector (prominent examples of such enterprises being those dealing in handicrafts, textiles, performing arts, studio design etc.) - is considered to be important in protecting, promoting and transmitting the heritage values of Albania to the younger generations. A research conducted by the local project of municipality Clusters \& Social Enterprises Incubators in the Field of Culture/ Tourism and Folk Tradition Inclust, (Interreg IPA
II Cross-Border Cooperation Program GreeceAlbania 2014-2020), Mapping and Evaluation of Cultural \& Creative Industry Organizations in the Area of Korça (City), identified the cultural and creative sectors and, among other things, analysed the role of these sectors in preparing young people for the preservation and promotion of cultural heritage elements. Based on the author's research conducted for the project, it can be that the heritage and cultural sector is one of

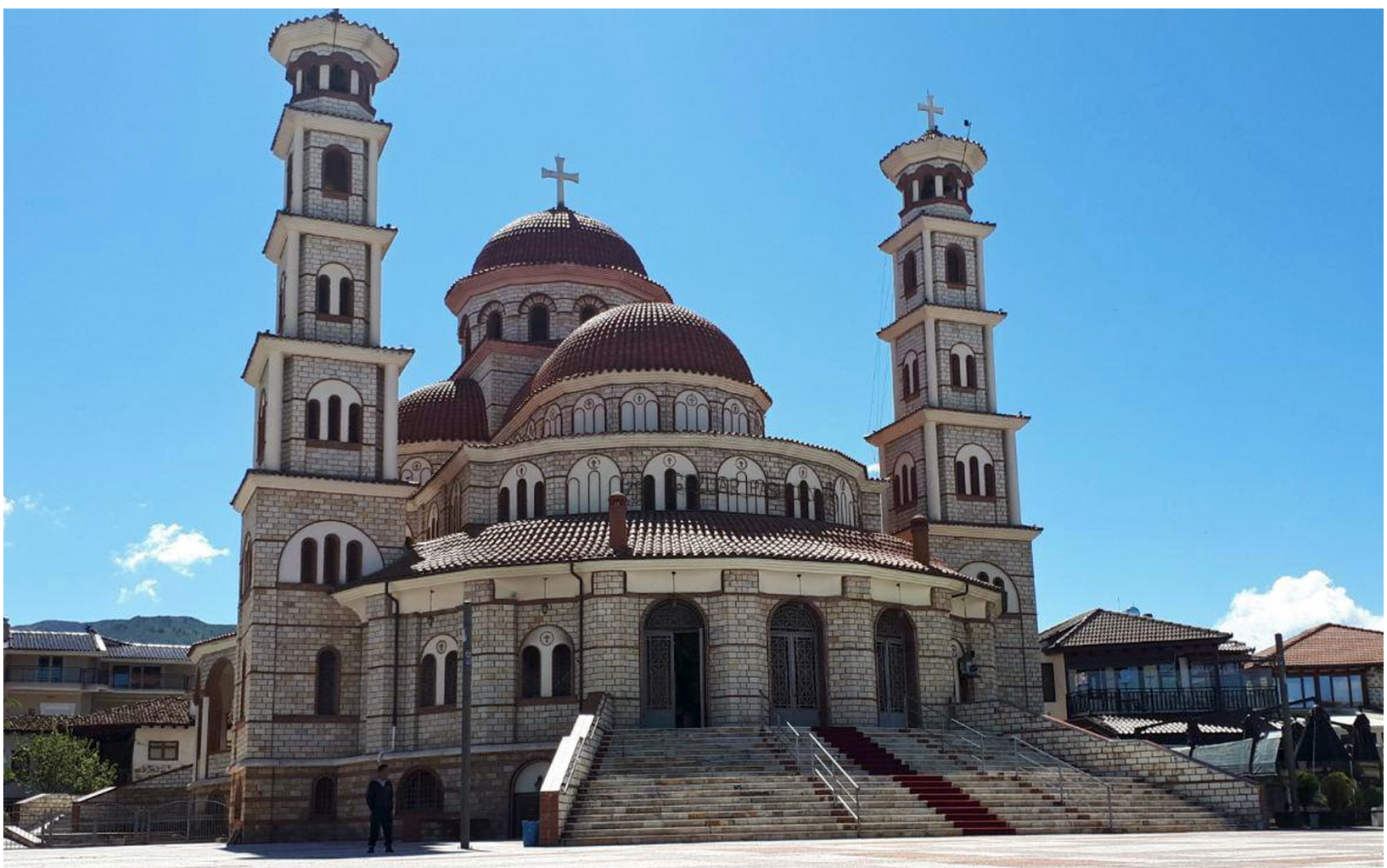

Fig. 2. The Ringjallja e Krishtit (Resurrection of Christ) Cathedral in the city of Korça.
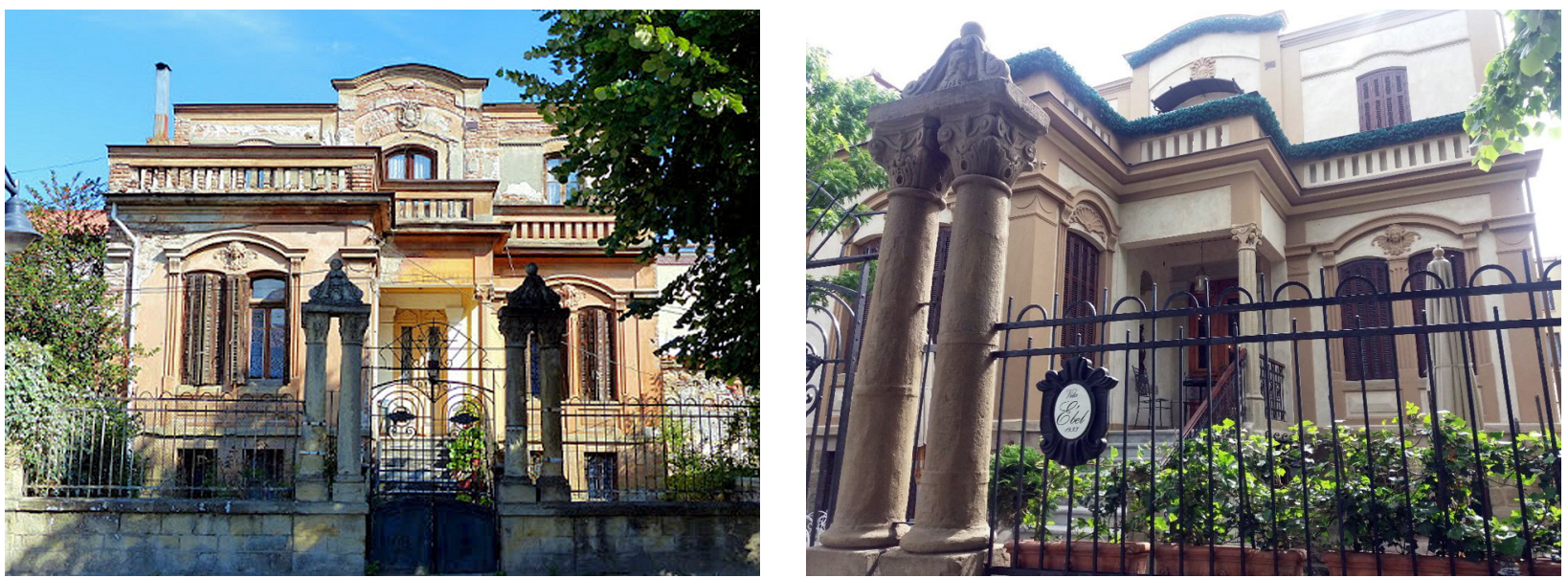

Fig. 3. A house building of 1933 before (left), actually Vila Ebel after restoration (right). 
the main sectors that can be considered developed and it is represented mainly by public institutions (museums, the theatre, the library etc.). Regarding the regular practices of cultural activities or events, all these institutions conduct cultural events on specific days and undertake activities in their premises to educate young people, school pupils and students. The vision of the institutions is to increase cultural activities and services for tourism development and especially the empowering of the connection between the youth and the Albanian cultural heritage (Menkshi, Braholli 2019). At the same time, performing arts and crafts sectors claim that their main activities consist of promoting and transmitting their traditions and heritage values through training of young people. Through these activities involving the cultural and creative sector, young people contribute in preservation of local and national cultural heritage elements. Furthermore, since the culture can consider one of the important component of sustainable development, the education for heritage and the engagement of youth in cultural and heritage activities can be consider as a means towards sustainable development (Gesche-Koning 2018).

The increasing of the accommodation structures and the businesses that develop activities in the tourism sector has created more opportunities for the employment of young people (Menkshi 2020). In this context the University of Korça can play an important role in preparing the skills of young people for the creative and cultural sectors especially by instituting 2-year courses for professions that the area has traditionally

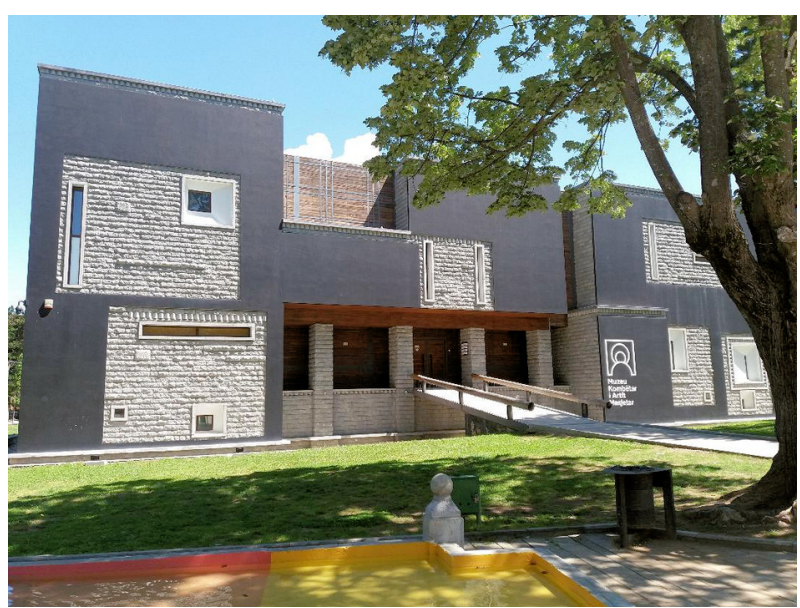

Fig. 4. National Museum of Medieval Art.

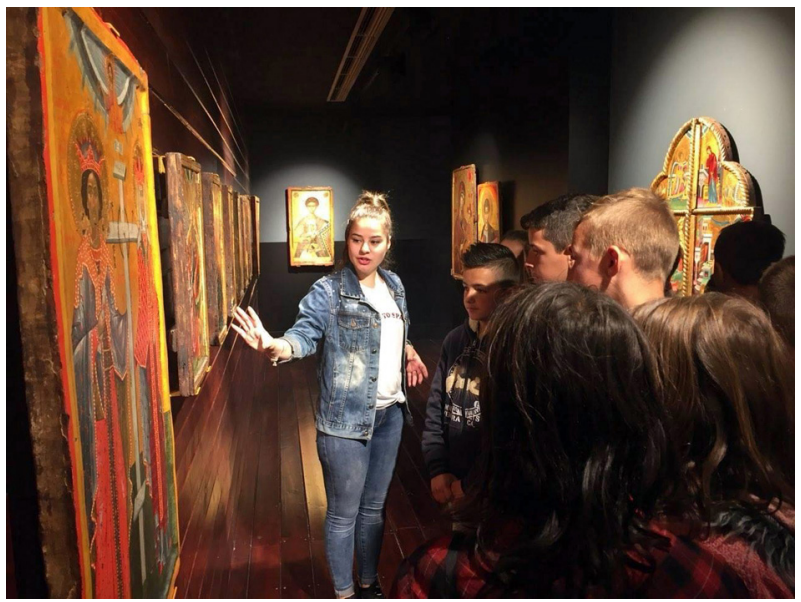

Fig. 5. A Geography student during voluntary practice in the museum.

developed over centuries of Cultural innovation. At the same time, thanks to the cooperation that the university has with local government and other institutions, there is already an established practice of engaging History and Geography students in voluntary 1-3 month internships in the city's museums, libraries, archives and cultural heritage sites (Figs 4, 5).

Also, the implementation of the Smile Albania project engages and at the same time employs many students and young people during the tourist season, and these promote tourist attractions at customs checkpoints, in the city and its surrounding areas. In addition to their engagement in the protection and preservation of culture and heritage, the young people play also an important role in promoting their values in social media.

\section{Methodology}

The research was carried out to identify and assess the level of engagement of young people in the preservation of cultural heritage and the promotion of their values in a tourist destination. The paper is based on quantitative and qualitative data provided by the literature and the conducted survey. To achieve the purpose of the study a questionnaire is distributed among a category of youth consisting of young people aged 15-29; the youth hail from high school and university. The goals of the study were the following elements:

- to evaluate the level of knowledge about local cultural heritage sites and their preservation; 
- to identify the engagement and youth contribution in cultural heritage activities, institutions and sites;

- to evaluate the students' interest to engage in promotion and preservation activities.

Given the difficult situation created by the Covid-19 pandemic, and the impossibility of individual contact, the questionnaire's distribution methods were both in-person (when it was possible) and via e-mail. The survey included young people from three of Korça's Public High Schools (there being only three in the city) and University students. The later were mainly from the History-Geography study program, but students from other programs were also included. In the case of high school students, participation in the survey was voluntary and the students initially expressed the desire to participate in the survey (students were first introduced to the topic of the survey). The History and Geography teachers provided the students' e-mail addresses to the authors. A total of 125 questionnaires were distributed (November-December 2020) to both genders, of which only 100 were completed. The questionnaire was designed by the authors and is divided into three sections, each of which consisted of questions that aimed to provide data for the purposes of the present study. The first section (A) provides some general data about the target group of respondents. The second section (B) aims to gather information about the knowledge of cultural heritage, the perceived importance of local heritage in the area and the importance of its protection and promotion. Finally, in the third section (C) consist of questions focussing on the involvement of students in the protection and promotion of heritage. The questions for which the opinion of the respondents was sought were both closed and open-ended. In section B, the open-ended questions were: 'What do you mean by cultural heritage?' and 'How do you understand the protection of cultural heritage?'; in section $C$ they were: 'In what activities or projects about cultural heritage have you been engaged?'; 'What kind of knowledge do you think you needed more during the project?'; 'What do you gain from engaging in these activities and projects?' and 'What contribution can young people make to the protection of cultural heritage?'. Among the other close-ended questions across the two main sections of the questionnaire, there are also four questions whose answers are measured with a Likert scale as follows:

1. Not at all important;

2. Not important;

3. Sufficiently important;

4. Important;

5. Very important.

The data gathered by the questionnaire was later coded and analysed using SPSS v. 20 software. Frequency tables, cross tabulation and the Kruskal-Wallis H-test were combined with qualitative data interpretation to achieve the goals of the research.

\section{Results and discussion}

Assessing the reliability of the questionnaire was the first step of our analysis process. The Cronbach's Alpha coefficient was calculated separately for each of the two main sections of the questionnaire and the obtained value showed that the survey is reliable, since the Alfa-value was > 0.7 (Bland, Altman 1997; Table 2).

A look into the demographic profile of the respondents indicates that from 100 participants in the research, the majority of respondents were female, 57 (57\%) and 43 (43\%) were male. Most of them live in Korça city (82\%) and only $18 \%$ live in the surrounding rural and urban areas. With regard to their age, the majority of young people surveyed $(43 \%)$ belong to the age group $15-17$ years, $28 \%$ to the age group 18-20 years and $17 \%$ to the age group 21-23 (Fig. 6). Also, the majority the respondents (54\%) attend high school, 25\% study for a bachelor's degree and $21 \%$ are pursuing/have completed a master's degree. (The survey aimed to include the same number of university students and high school students but not all of them responded to the questionnaire.) Out of the bachelor [46\% $(n=46)]$ and master university students, ([23\% $(n=23)]$ stated that they belong to the history-geography study program and $23 \%(n=23)$ stated that they belonged to other programs (tourism, administration and social policy, primary education etc.).

Table 2. Reliability statistics.

\begin{tabular}{|c|c|c|}
\hline Section & Cronbach's alpha & No of items \\
\hline B & 0.819 & 14 \\
\hline C & 0.827 & 13 \\
\hline
\end{tabular}



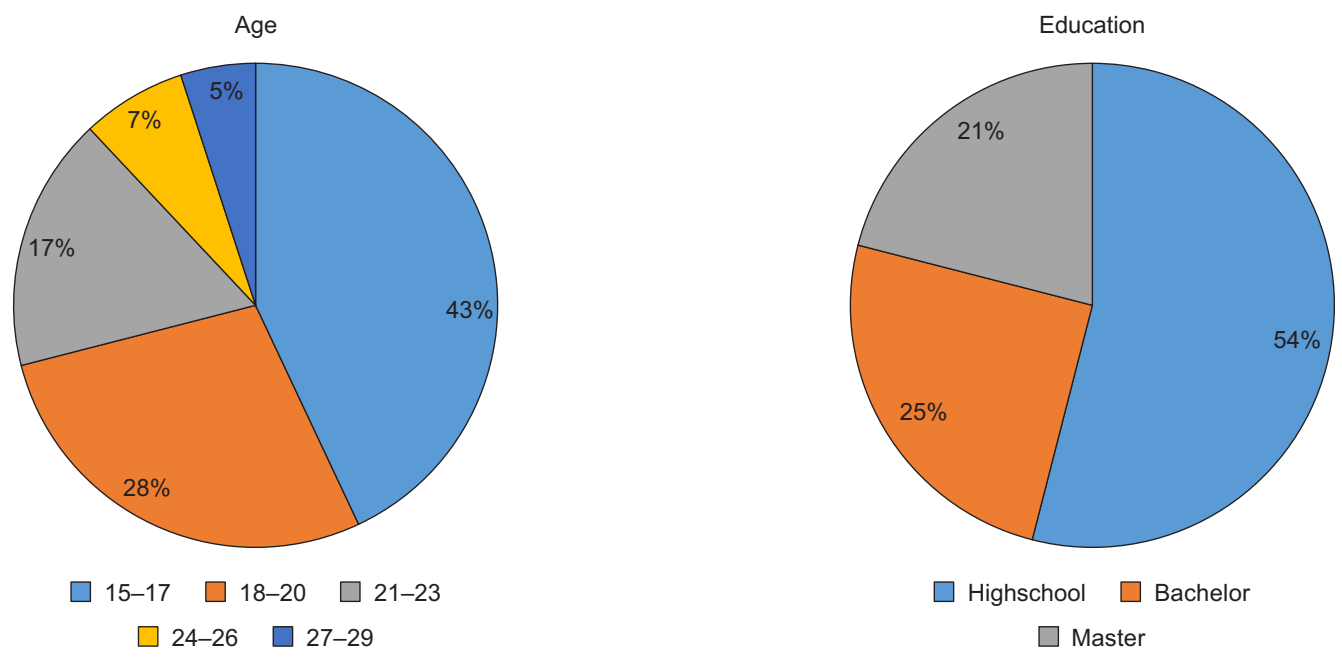

Fig. 6. Age and education level of respondents.

\section{Evaluating the level of knowledge about cultural heritage, local sites and their preservation}

To assess their level of knowledge, respondents were initially asked about the meaning of the term cultural heritage, how much they know about the cultural heritage values of the area wherein they live, how much they value them, what they understood by the concept of protection of cultural values and how important they consider it to be. Specifically, being asked about what they understand to be cultural heritage, the respondents have responded with different opinions. Most of the high school students have a good perception claiming that cultural heritage means archaeological objects, religious objects, songs, dances and many other things that we have inherited from the past. Only a few of them have specified to be transmitted to the future generation. The meaning of cultural heritage is broader and more complete in the opinion of university students, especially those who have completed a bachelor's degree in History-Geography. According to the opinions expressed, they define cultural heritage as tangible and intangible values of human society, monuments, buildings, sites, museums, religious objects, traditions, language, songs, music, celebrations etc. inherited from the past and that should be transmitted to the future. Better knowledge about the concept of culture heritage by students of the History and Geography study program (bachelor and master)

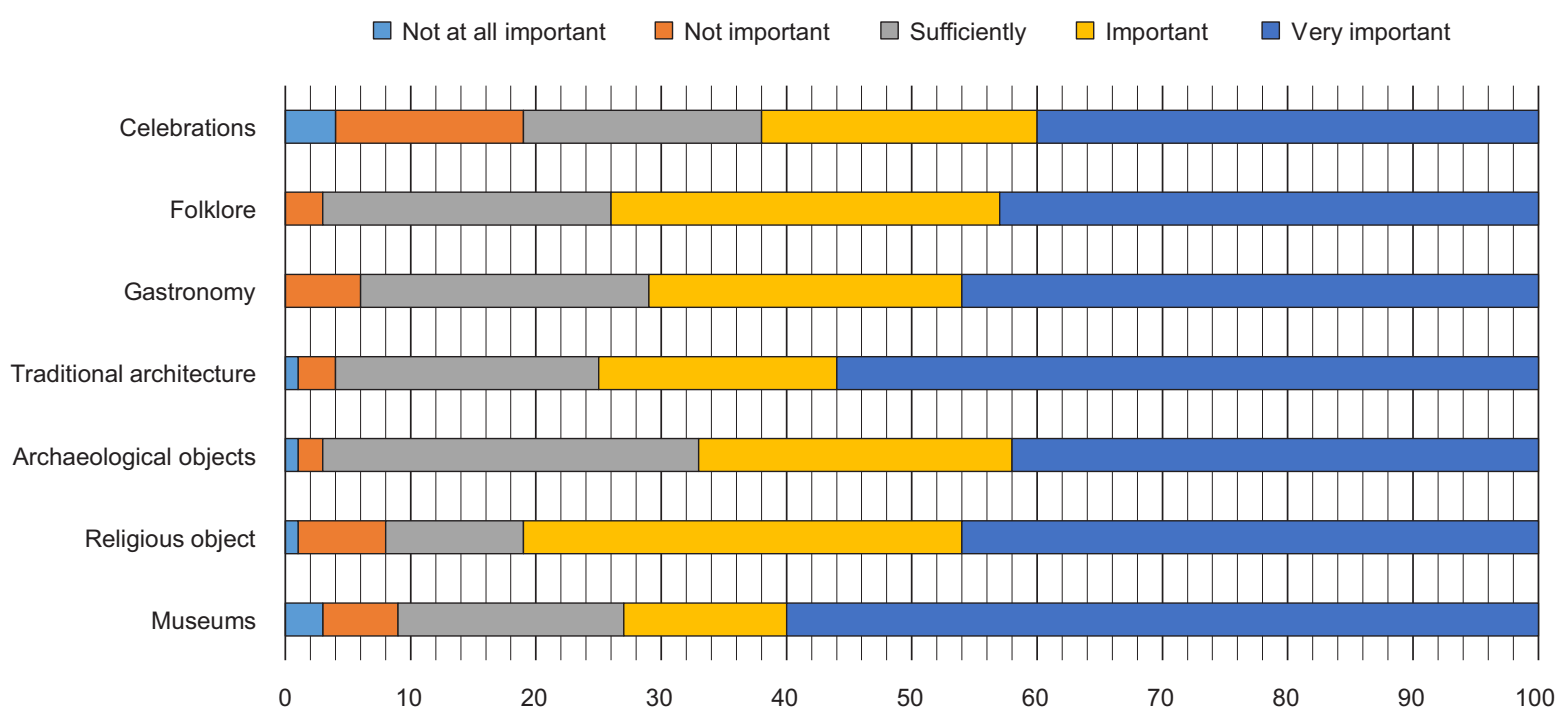

Fig. 7. Respondent's assessment of the importance of cultural attractions. 
is related to the specific subjects of heritage that they have developed. To identify the level of knowledge about local heritage, the participants in the survey were asked whether they know these values and how important each of them is as a tourist attraction. Most of the respondents $(89 \%)$ stated that they knew the local heritage through some objects located in the cities and the surrounding area, while $82 \%$ of the respondents stated that they knew the values of these objects to some extent. To get young people's opinions on the importance of some elements of tangible and intangible cultural heritage as tourist attractions, we presented some key elements and they expressed their opinion through Likert-scaled answers that ranged from 1 (not at all important) to 5 (very important). According to their assessment, most of the respondents $(60 \%)$ evaluate as very important tourist attractions the city museums, traditional architecture (56\%) (the old bazaar, traditional buildings), religious objects $(46 \%)$, gastronomy $(46 \%)$, folklore $(43 \%)$, archaeological sites (42\%) and festivals (40\%). While we perceive the figures obtained, most of the young

Table 3. Crosstabs table.

\begin{tabular}{|c|c|c|c|c|c|c|c|}
\hline \multirow{3}{*}{\multicolumn{2}{|c|}{$\begin{array}{l}\text { Respondents' assessment of the importance } \\
\text { of the cultural attraction }\end{array}$}} & \multicolumn{6}{|c|}{ Education Level } \\
\hline & & \multicolumn{2}{|c|}{ High school } & \multicolumn{2}{|c|}{ Bachelor } & \multicolumn{2}{|c|}{ Master } \\
\hline & & \multicolumn{6}{|c|}{$[\%]$} \\
\hline \multirow{5}{*}{ 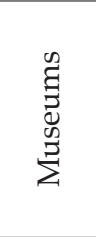 } & Not at all important & 3 & 5.6 & 0 & 0 & 0 & 0.0 \\
\hline & Not important & 3 & 5.6 & 1 & 4 & 2 & 9.5 \\
\hline & Sufficiently & 10 & 18.5 & 4 & 16 & 4 & 19.0 \\
\hline & Important & 9 & 16.7 & 3 & 12 & 1 & 4.8 \\
\hline & Very important & 29 & 53.7 & 17 & 68 & 14 & 66.7 \\
\hline \multirow{5}{*}{ 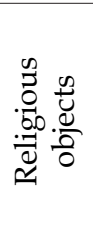 } & Not at all important & 1 & 1.9 & 0 & 0 & 0 & 0.0 \\
\hline & Not important & 5 & 9.3 & 0 & 0 & 2 & 9.5 \\
\hline & Sufficiently & 9 & 16.7 & 0 & 0 & 2 & 9.5 \\
\hline & Important & 17 & 31.5 & 10 & 40 & 8 & 38.1 \\
\hline & Very important & 22 & 40.7 & 15 & 60 & 9 & 42.9 \\
\hline \multirow{5}{*}{ 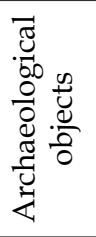 } & Not at all important & 1 & 1.9 & 0 & 0 & 0 & 0.0 \\
\hline & Not important & 2 & 3.7 & 0 & 0 & 0 & 0.0 \\
\hline & Sufficiently & 19 & 35.2 & 5 & 20 & 6 & 28.6 \\
\hline & Important & 16 & 29.6 & 4 & 16 & 5 & 23.8 \\
\hline & Very important & 16 & 29.6 & 16 & 64 & 10 & 47.6 \\
\hline \multirow{5}{*}{ 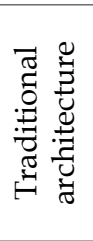 } & Not at all important & 1 & 1.9 & 0 & 0 & 0 & 0.0 \\
\hline & Not important & 3 & 5.6 & 0 & 0 & 0 & 0.0 \\
\hline & Sufficiently & 13 & 24.1 & 5 & 20 & 3 & 14.3 \\
\hline & Important & 10 & 18.5 & 7 & 28 & 2 & 9.5 \\
\hline & Very important & 27 & 50.0 & 13 & 52 & 16 & 76.2 \\
\hline \multirow{4}{*}{ 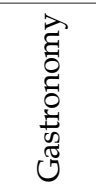 } & Not important & 6 & 11.1 & 0 & 0 & 0 & 0.0 \\
\hline & Sufficiently & 11 & 20.4 & 8 & 32 & 4 & 19.0 \\
\hline & Important & 11 & 20.4 & 9 & 36 & 5 & 23.8 \\
\hline & Very important & 26 & 48.1 & 8 & 32 & 12 & 57.1 \\
\hline \multirow{4}{*}{$\begin{array}{l}0 \\
\frac{0}{0} \\
\stackrel{y}{0} \\
0 \\
1\end{array}$} & Not important & 3 & 5.6 & 0 & 0 & 0 & 0.0 \\
\hline & Sufficiently & 13 & 24.1 & 7 & 28 & 3 & 14.3 \\
\hline & Important & 14 & 25.9 & 11 & 44 & 6 & 28.6 \\
\hline & Very important & 24 & 44.4 & 7 & 28 & 12 & 57.1 \\
\hline \multirow{5}{*}{ 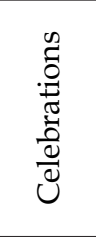 } & Not at all important & 3 & 5.6 & 0 & 0 & 1 & 4.8 \\
\hline & Not important & 11 & 20.4 & 2 & 8 & 2 & 9.5 \\
\hline & Sufficiently & 8 & 14.8 & 5 & 20 & 6 & 28.6 \\
\hline & Important & 11 & 20.4 & 7 & 28 & 4 & 19.0 \\
\hline & Very important & 21 & 38.9 & 11 & 44 & 8 & 38.1 \\
\hline
\end{tabular}


people whose opinion was solicited as part of the questionnaire evaluate religious objects to be highly attractive and important domestic as well as international tourist destinations (Fig. 7).

By cross tabulating the data gathered from the assessment given for the cultural attractions with the three levels of education of the respondents (Table 3), it is discovered that most bachelor and masters students considered museums, archaeological sites, architecture and religious objects as very important attractions. On the other hand, most of high school students consider gastronomy, folklore (music) and celebrations as very important. The selection of museums and other sites of tangible heritage may be explained by student's knowledge of the importance that these sites present as attractions for income generation, i.e., tourism.

The young people who participated in the survey were also asked where they acquired most of their knowledge about heritage values (secondary education, high school, bachelor). $51 \%$ (amounting to most) of the participants answered that they have gained knowledge in high school, $25 \%$ in bachelor, $21 \%$ in secondary education and $3 \%$ did not respond. Contemplating this statement, we suggest that by expanding heritage knowledge in the high school curriculum as well as by getting involved in different cultural activities through informal education, high school can play an important role in heritage education among young people of this age group and others who study different programs in university.

When asked about their perception of cultural heritage preservation, most of the respondents $(52 \%)$ share the same opinion, perceiving it as protection from destruction. In addition to this, students of History and Geography, in their statements, consider the protection of cultural heritage as preservation, reconstruction and maintenance of original values. Moreover, the question of how important the preservation of local heritage is considered to be (based on another Likert scale), $62 \%$ (amounting to a majority of the respondents) consider it to be very important, $21 \%$ important, $11 \%$ less important, 5\% sufficiently important and $1 \%$ not important. In general, the majority of young people $(83 \%)$ favourably consider the importance of preserving culture heritage. Also, regarding the question of how important young people consider the promotion of cultural heritage for the development of tourism in their area, we have ascertained that 59\% consider it very important, $20 \%$ important, $13 \%$ sufficiently important and $8 \%$ less important. In both the above questions there is a number of students who express reservations about the protection and promotion of local heritage values. They are young people who have stated that they don't know the values of local cultural heritage. When it comes to the question of whether local government and responsible institutions do their best to protect and promote cultural heritage, most of them $(61 \%)$ say no and the remainder $(39 \%)$ say yes. When asked what should they do more?, $54 \%$ of those who answered (no) among other responses emphasise that the values of cultural attractions should be promoted more in Albania but also abroad. History-Geography students $(n=23)$ also emphasise the need for more investment in their maintenance and preservation of values from alienation because of urban development.

\section{Identifying the youth engagement in preservation of cultural heritage and their contribution in promotion}

In order to identify the involvement of young people in activities for the protection and promotion of cultural heritage, we initially wanted to find out if the respondents were part of any youth structure or youth network in the country. Asked about this, most of the respondents $(82 \%)$ have stated that they are not part of any structure or youth organisation in the country and only $18 \%$ of them have stated that they are involved in some structures such as youth centres in Korça and the youth network in Albania. (Non-involvement in youth structures or networks in the country can be explained by the fact that there are not many youth structures in Albania and they are mainly oriented towards the involvement of young people in decision-making.)

When asked 'Have you ever participated in activities or projects related to the protection and promotion of cultural heritage?', 59\% of the respondents answered that they have never participated in cultural projects and activities and $41 \%$ of them said yes. Next, the latter have specified that their engagement consisted of being part of the national heritage promotion project Smile Albania, voluntary practice (guide) in 

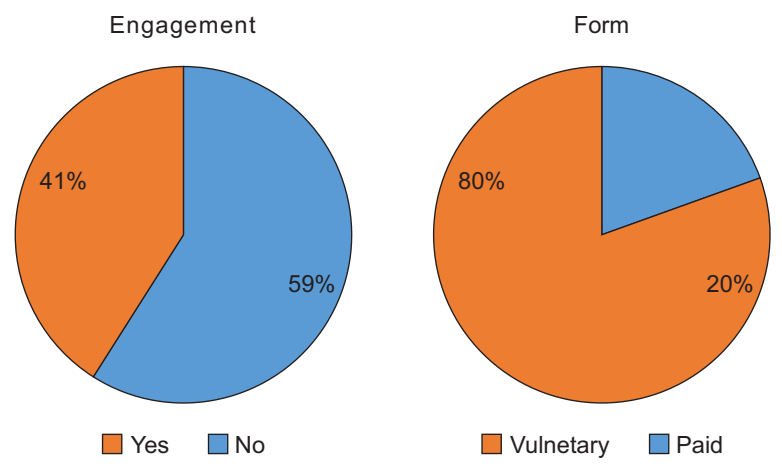

Fig. 8. The level of engagement of young people and the form of engagement.

the city's museums, participation in summer schools such as Living between cultures?, initiated by the Institute for Democracy Media and Culture (IDMC), guides for foreign tourists who have visited the area and Albania, participation in fairs and celebrations promoting local tangible and intangible values, workshops organised by the Ministry of Culture or other institutions to promote heritage etc. Moreover, $63.4 \%(n=26)$ of the engaged students revealed that they were informed about these projects by the announcements made by the local government and other institutions, $26.8 \%(n=11)$ in the university by the professors of their study program and $9.8 \%$ $(n=4)$ by the announcements on social networks. The majority of the engaged respondents $(n=33)$ stated that their work was voluntary and the rest of them $(n=8)$ indicated that they were paid (Fig. 8).

Regarding the duration of these engagements, for $36.6 \%(n=15)$ of the engaged respondents it lasted for 1 day; for $26.8 \%(n=11)$ of them it lasted

Table 4. Ranks of perceived knowledge and abilities.

\begin{tabular}{|l|r|c|}
\hline \multicolumn{1}{|c|}{ Study program } & N & Mean rank \\
\hline High School & 21 & 14.21 \\
\hline History-Geography & $\mathbf{1 4}$ & $\mathbf{2 9 . 6 8}$ \\
\hline Administration and social policy & 2 & 24.50 \\
\hline IT & 1 & 12.00 \\
\hline Biology-Chemistry & 1 & 12.00 \\
\hline Philosophy-Sociology & 2 & 24.50 \\
\hline Total & 41 & \\
\hline
\end{tabular}

Table 5. Kruskal Wallis Test for perceived knowledge and abilities.

\begin{tabular}{|c|c|}
\hline Chi-Square & 18.497 \\
\hline Df & 5 \\
\hline Asymp. Sig. & 0.002 \\
\hline a. Grouping Variable: Study program \\
\hline
\end{tabular}

several days; for $19.5 \%(n=8)$ of them it lasted for 1 month and for $17.1 \%(n=7)$ it lasted for more than a month. Asked 'Have your knowledge and skills been valuable for your commitment?', $51.2 \%(n=21)$ of the engaged respondents said that they were sufficient, $24.3 \%$ said they were good, $22.0 \%$ very good and $2.5 \%$ insufficient.

To further analyse the relation between the perceived knowledge and abilities and the level of education of the respondents the Kruskal-Wallis $\mathrm{H}$-test was performed. The test showed that there was a statistically significant difference in the respondents' perceived knowledge and abilities with regard to their study program and level of education, with $c^{2}(5)=22.537$ and $p<0.05$ (Table 5). The highest mean rank is 29.68 and belongs to students of History-Geography, and the lowest is 12.00 and belongs to IT, Biology and Chemistry students. Tables 4 and 5, show that these history and geography students (which are also the ones with better knowledge) have experienced fewer difficulties in their project engagement and feel more secure in their abilities. At the same time, this prompts us to think that the more knowledge the Albanian youth have about cultural heritage, the more confident they will be in their abilities, which also could generate more interest in this kind of activities.

Lastly, in terms of the knowledge and skills they needed when engaging in activities, most of the respondents have identified the need to combine theoretical knowledge with practice, the need for more knowledge about the values of national heritage obtained from experience in practice etc.

\section{Evaluating the students' interest to engage in promotion and preservation activities}

Most of the respondents (79\%), expressed interest and desire in engaging in promotion and preservation of culture heritage activities, but highlighted the fact that there are not many activities in the field of heritage protection. When asked 'What do you expect to benefit from engaging in such activities and projects?', young people say that such activities help them to acquire new knowledge, gain experience, raise their awareness for the protection of cultural values, expand their contacts with other young people, share experiences and knowledge with young people and 


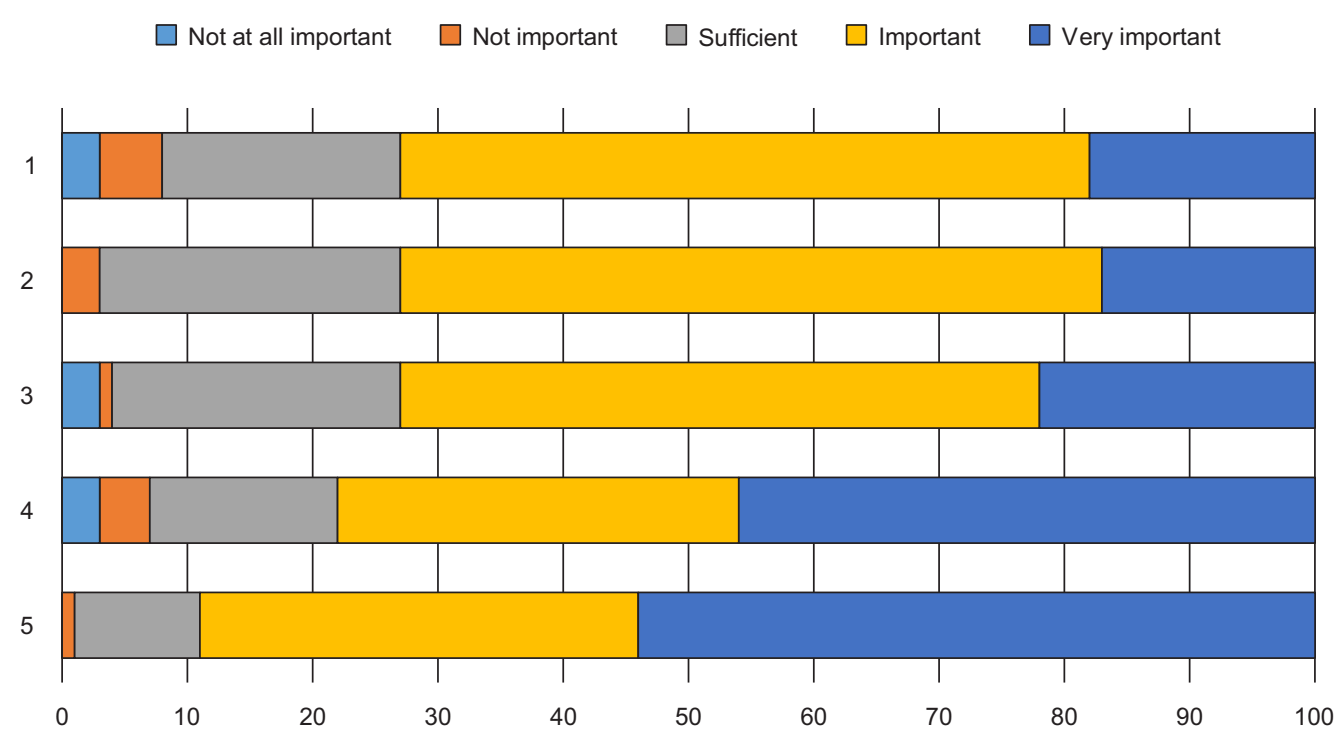

Fig. 9. Respondents assessment of factors that may increase their engagement.

1 - expanding the knowledge in the respective study program, 2 - integrating more knowledge in other related programs, 3 - expanding the knowledge in the lowest levels of education, 4 - more trainings, workshops, field trips etc.,

5 - more encouragement from the local government and other organisation to take part in activities and projects.

other people etc. A graduate student in HistoryGeography expresses, through commitment I gain experience, learn more about cultural heritage so I can give my contribution to its promotion.

The young people who participated in the study were next asked 'What do you think would increase the engagement of young people in the protection and promotion of heritage in your destination?' Through the Likert-scaled answers furnished by the respondents, it has been ascertained that the respondents who consider increasing the interest of local government and cultural institutions to involve them in activities and projects with this interest as very important are $54 \%$ and important, 35\% (Fig. 9).

In addition, they consider important (51\%) and very important $(22 \%)$ the expansion of knowledge about heritage from the lowest levels of education, and also very important $(46 \%)$ and important $(32 \%)$ the involvement in more field trips, trainings, workshops etc.

Meanwhile, it is interesting to observe that the number of young people who think to be important $((55 \% ; n=55)$ and very important $((18 \%$; $n=18)$ integrating more knowledge in other related programs, could explain the deficiencies identified in high school curriculum and in study programs related to culture heritage, tourism or other disciplines. We suggest that it is also a necessity to increase the sufficient level of knowledge of the youngest people engaged in projects and cultural activities. Finally, $90 \%$ of the respondents reacted positively to the statement that students can play an important role in preserving and promoting heritage values in the destination, while $10 \%$ did not agree.

\section{Conclusions and recommendation}

The engagement of young people in the protection and promotion of cultural heritage is already considered to be a necessity by international organisations, institutions in charge of the protection of cultural heritage and beyond. Heritage education, in the pre-university education curriculum, empowers students to gather knowledge and awareness of cultural values and inculcate within themselves the importance of preservation and transmission of heritage and culture to future generations. In the education system in Albania, heritage education is included in all levels of pre-university education, but on the basis of consultations with the literature, the subject of cultural heritage is studied largely in the disciplines of geography and history. Even in these disciplines the teaching of heritage knowledge is limited. At this point, we would suggest revising the curriculum and expanding knowledge in these disciplines. At the same time, we would consider it necessary to involve teachers in trainings, workshops and seminars for their 
professional growth in terms of heritage education. As regards the survey analysed above, we highlight the fact that the level of awareness among most young people interviewed, regarding cultural heritage, its local values and their protection, is high. The level of their engagement in cultural activities and heritage protection and promotion projects is at an average level. In particular, it is low in those high school students who were afforded the opportunity to respond to our questionnaire. In addition, the desire of most young people surveyed to engage not merely voluntarily but also contribute through other forms of participation remains high.

While the majority of young people express the desire to engage in such activities and the role of local government and cultural institutions that are considered important in their engagement, the latter can use this willingness in organising events, celebrations and activities, which require resources that can be rendered available through youth engagement; these youth may have acquired skills and knowledge through funded education programs. For instance, in the case of organising the Beer Festival or other celebrations during the tourist season, local authorities have always been notified of students' interest in volunteering. From the results of students with work experiences as well as from the survey, it is clearly evidenced that the students of history and geography programs possess good knowledge and skills to engage in voluntary practices in cultural heritage sites in the city and the region. Through the initiatives of Regional Directorate of Culture Heritage and the local government, students can contribute during their studies, through field work, to the maintenance of the visit-worthiness of archaeological sites, monuments and museums by accompanying tourists and domestic visitors in their trips to tourist attractions etc.

\section{Limitations of the study}

The study is a modest attempt by authors to assess the level of youth engagement in the protection and promotion of cultural heritage in a local area. Since the study was conducted during Covid-19, the available time and scope was limited. We suggest undertaking future studies in which there is inclusion of a larger group of young people throughout the country.

\section{Acknowledgments}

This study was undertaken at the initiative of the Geography Lecturers of Fan S. Noli University and was carried out in collaboration with two authors from other fields. It is not supported by any funding source. The authors would like to thank the high school teachers, students of the three public high schools in the city of Korça, students of the department of History and Geography as well as students and other young people who collaborated completing the survey.

We would also like to thank the two anonymous reviewer suggestions and constructive comments during the review process.

\section{Author's contribution}

Edlira Menkshi contributed to the conception, literature review, survey analysis and writing the paper. Ermiona Braholli compiled the map of cultural heritage and contributed to the completion of the questionnaires. Silvja Cobani processed the questionnaires based in SPSS method and presented the results graphically. While Diana Shehu contributed to the design of the questionnaires.

\section{References}

Bland J.M., Altman D.G., 1997. Statistics, notes: Cronbach's alpha. BMJ 314: 572. DOI 10.1136/bmj.314.7080.572.

CE [Council of Europe], 2005. Convention on Values of Cultural Heritage for Society. Faro, Portugal. Council of Europe Treaty Series - No. 199: 1-9. Online: rm.coe. int/1680083746 (accessed February 28, 2021).

CE [Council of Europe], 2018. European Cultural Heritage Strategy of 21st Century. Council of Europe, 1-83. Online: rm.coe.int/european-heritage-strategy-for-the-21st-century-strategy-21-full-text/16808ae270 (accessed February 28,2021 )

Chapuis M., Lydon A., Brandt-Grau A. (eds), 2009. Preserving our heritage, improving our environment. Vol. II Cultural heritage research: FP5, FP6 and related projects. European Communities, 2-243. Online: http://www.eurosfaire. prd.fr/7pc/doc/1263283040_20years_cultural_heritage_ vol2_en.pdf (accessed February 28, 2021).

CRCA [Child Rights Centre Albania], 2018. Youth in Albania: Report and National Index of Assessment for Implementation of National Action Plan for Youth in Albania. CRCA Shqipëri 2018. 3-65. Online: www.crca.al/sites/ default/files / publications/YOUTH\% 20IN\% 20ALBANIA\%202015-2017.pdf (accessed February 28, 2021).

CRCA/ECPAT Albania, [Child Rights Centre Albania], 2020. Raporti Kombëtar: Rinia në Shqipëri 2020. CRCA/ECPAT Shqipëri. 2-48. Online: www.crca.al/sites/default/files/ publications/RAPORTI\%20TE\%20RINJTE\% 20NE\% 20 SHQIPERI\%202019-2020_0.pdf (accessed February 28, 2021).

EC [European Commission], 2018. Youth for Heritage: Young People Bringing New Life to Heritage. Online: europa.eu/ 
cultural-heritage/sites/eych/files/3-youth-for-heritage-10-european-initiatives-factsheet_en.pdf (accessed February 28, 2021).

Escribano-Miralles A., Martínez P.M., Serrano-Pastor F.J., 2020. Heritage and Museums as Objects of Education for Citizenship in the Teaching of History. In: E.J.Delgado-Algarra, J.M.Cuenca-López (eds), Handbook of Research on Citizenship and Heritage Education, IGI Global, Information Science Reference, Hershey: 103-125. DOI 10.4018/978-1-7998-1978-3.ch006.

FCAPT [Faro Convention Action Plan Team], 2018. The Faro Convention Action Plan Handbook 2018-2019. Faro Convention Network 1-30. Online: rm.coe.int/faro-convention-action-plan-handbook-2018-2019/168079029c (accessed February 28, 2021).

Gesche-Koning N., 2018. Research for CULT Committee-Education in Culture Heritage. European Parliament, Policy Department for Structural and Cohesion Policies, Brussels: 3-50. Online: www.europarl.europa.eu/RegData/ etudes/STUD/2018/617486/IPOL_STU(2018)617486_ EN.pdf (accessed February 28, 2021).

Hani U., Azzadina I., Sianipar C.P.M., Setyagung E.H., Ishii T., 2012. Preserving cultural heritage through creative industry: A lesson from Saung Angklung Udjo. Procedia Economics and Finance 4: 193-200. DOI 10.1016/S22125671(12)00334-6.

Jagielska-Burduk A., Stec P., 2019. Council of Europe Cultural Heritage and Education Policy: Preserving identity and searching for a common core? Revista Electronica Interuniversitaria de Formacion del Profesorado 22(1): 1-12. DOI 10.6018/reifop.22.1.354641.

Karadeniz C.B., 2020. Assessment for awareness and perception of the cultural heritage of geography students. Review of International Geographical Education 10(1): 40-64. DOI 10.33403 rigeo.640722.

KM [Këshilli i Ministrave], 2018. Ligji Për Trashëgiminë Kulturore dhe Muzetë. (Low For Cultural Heritage and Museums) Kuvendi i Republikës së Shqipërisë. Online: kultura. gov.al/wp-content/uploads/2018/07/Ligji.nr27-_dt.1705-2018.pdf (accessed February 28, 2021).

Menkshi E., 2014. Trashëgimia Kulturore në Funksion të Zhvillimit të Qarkut Korçë. PhD Dissertation, MS, Universiteti i Tiranës, Tiranë.

Menkshi E., 2020. Trashëgimia Kulturore dhe Natyrore e Qarkut Korçë, Vlerat dhe Përdorimi turistik. Promo Print, Korçë: 120-140.

Menkshi E., Braholli E., 2019. The mapping and evaluation of cultural and creative industry in Korca City. Knowledge International Journal 35(3): 799-804.

Menkshi E., Braholli E., 2020. Urban tourism development and tourist survey in Korça City. Knowledge International Journal 40(1): 237-242.

MESR [Ministria e Arsimit, Sporteve dhe Rinisë], 2017. Kurrikula me Zgjedhje, Lënda Gjeografi. MESR. Tiranë: 2-46.

MESR [Ministria e Arsimit, Sporteve dhe Rinisë], 2019. Kurrikula Bazuar në Kompetenca, Lënda Gjeografi, Klasa e IX. MESR.Tiranë: 2-79.

MK [Ministria e Kulturës], 2019. Strategjia Kombëtare për Kulturën 2019-2025. Tiranë.

MMSR [Ministria e Mirëqënies Sociale dhe Rinisë], 2015. Plani Kombëtar për Rininë, 2015-2020. MMSR. Tiranë. Online: www.un.org.al/sites/default/files/plani\%20 kombetar\%20i\%20veprimit\%20per\%20rinine \%2020152020_Shqip.pdf (accessed February 28, 2021).
MTKR [Ministria e Turizmit, Kulturës dhe Rinisë], 2006. Srategjia Kombëtare e Rinisë (2007-2013). MTKR. Tiranë: 3-86.

MTM [Ministria e Turizmit dhe Mjedisit], 2018. Turizmi në shifra 2018. Tiranë.

Peci D., Nikolli X., 2017. Vështrim mbi politikat rinore ne Shqipëri. Analizë në nivel qendror dhe lokal 2015-2019.Tiranë.

Selenica E., 1982. Korça në faqet e historisë. 8 Nëntori 3-64.

Spiridon P., Kosic M., Tuci B., 2014. Cre-Active Youth Promoting Cultural Heritage for Tomorrow. Journal of Interdisciplinary Research. Online: www.researchgate.net/ publication/305490149 (accessed February 28, 2021).

UE [European Union], 2011. The Preservation and Enhancement of Cultural Heritage in Mediterranean. Online: cor.europa. eu/en/engage/studies/Documents/preservation-cultural-heritage-mediterranean.pdf (accessed February 28, 2021).

UN [United Nations], (n.d.). Culture and Youth Development. United Nation. Online: www.un.org/esa/socdev/documents/youth/fact-sheets/youth-cultureasavector.pdf (accessed February 28, 2021).

UNESCO [United Nations Educational, Scientific and Cultural Organization], 1972. Convention Concerning the Protection of the World Cultural and Natural Heritage. Online: whc. unesco.org/en/convention (accessed February 28, 2021).

UNESCO [United Nations Educational, Scientific and Cultural Organization], 2003. Convention for Safeguarding of the Intangible Cultural Heritage. Online: http:/ / orcp.hustoj.com/convention-for-the-safeguarding-of-the-intangible-cultural-heritage-2003/ (accessed February 28, 2021).

UNESCO [United Nations Educational, Scientific and Cultural Organization], (n.d.). Strengthening the role of youth in heritage safeguarding and cultural tourism development in CIS countries (2014-2017). Online: http://www.unesco. org/new/fileadmin/MULTIMEDIA/FIELD/Moscow / pdf/MP1-ED/BROCHURE_FINAL_en_03.pdf (accessed February 28, 2021).

UNESCO [United Nations Educational, Scientific and Cultural Organization], 2019. Community based inventory of ICH in Albania with a view to safeguarding and transmitting to future generations. Online: ich.unesco.org/en/ assistances/community-based-inventory-of-ich-in-albania-with-a-view-to-safeguarding-and-transmitting-to-future-generations-01253 (accessed February 28, 2021).

UNESCO [United Nations Educational, Scientific and Cultural Organization], 2020a. Lists of Intangible Cultural Heritage and the Register of good safeguarding practices. Online: http://ich.unesco.org/en/lists (accessed February 28, 2021).

UNESCO [United Nations Educational, Scientific and Cultural Organization], 2020b. World Heritage List. Online: http://whc.unesco.org/en/list/ (accessed February 28, 2021).

UNESCO [United Nations Educational, Scientific and Cultural Organization], (n.d.). World Heritage Education Programme. Online: http://whc.unesco.org/en/wheducation/ (accessed February 28, 2021).

UNESCO [United Nations Educational, Scientific and Cultural Organization], 2019. Engaging youth for inclusive and sustainable Europe. Online: ich.unesco.org/en/ engaging-youth-for-an-inclusive-and-sustainable-europe-01051 (accessed February 28, 2021).

Yahaya A., 2006. The scope and definition of heritage: From tangible to intangible. International Journal of Heritage 12(3): 292-300. DOI 10.1080/13527250600604639. 